\title{
Common names for all species and subspecies of the genus Anguilla
}

\author{
Katsumi Tsukamoto $•$ Mari Kuroki $\mathbb{D} \cdot$ Shun Watanabe $\mathbb{C}$
}

Received: 11 March 2020 /Revised: 11 March 2020 / Accepted: 22 May 2020 / Published online: 19 June 2020

(C) The Author(s) 2020

\begin{abstract}
Scientific naming rules of animals are strictly defined by the International Code of Zoological Nomenclature, while those for common names are vague and not well defined. Specifically, the common names of freshwater eels of the genus Anguilla have become confused among scientific papers, pictorial books, and online resources in recent years. This disordered use of common names among freshwater eels demonstrates the urgent need for the standardization of common names for these species. In addition, freshwater eel populations have drastically decreased worldwide over the past few decades, resulting in their listing as endangered species. In the present study, we defined the following five rules for the common names of freshwater eels: to (1) use a representative locality name of the geographic distribution of the species or subspecies, (2) distinguish two sympatric species or subspecies as longfin or shortfin, (3) select a name that would enable the scientific name to be easily recalled, (4) value longstanding former common names if they adhere to the above three rules, and (5) use the shortest name possible. Based on current scientific knowledge and on these rules, we proposed 22 common names for all known 19 species and sub-
\end{abstract}

\footnotetext{
K. Tsukamoto $\cdot$ M. Kuroki

Department of Aquatic Bioscience, Graduate School of Agricultural and Life Sciences, The University of Tokyo, Tokyo 113-8657, Japan

S. Watanabe $(\bowtie)$

Department of Fisheries, Faculty of Agriculture, Kindai University, Nara 631-8505, Japan

e-mail: swpc@nara.kindai.ac.jp
}

species of the genus. As a result, 21, 6, 13, and 3 species and subspecies were named based on Rules (1), (2), (3), and (4), respectively.

Keywords Freshwater eel $\cdot$ Anguillidae $\cdot$ Common name $\cdot$ Scientific name

\section{Introduction}

Scientific names of animals are strictly defined by the International Code of Zoological Nomenclature stipulated by the International Commission on Zoological Nomenclature (https://www.iczn.org; Accessed 03 March 2020). However, common names are not defined by any set of rules. Although the majority of common names used are spontaneously decided on in many cases, there can be confusion when a species has two or more different common names or if a single common name is used for multiple species, e.g., among the common names of anguillid eels. Common names are considered to be effective when they are short and simple, and thus easily remembered, and organized systematically according to a certain rule.

Currently, 19 species and subspecies of Anguillid eels are recognized worldwide (Ege 1939; Castle and Williamson 1974; Watanabe et al. 2009a) (Fig. 1). These species and subspecies are all distinguishable by molecular characteristics (Watanabe et al. 2005), although there are still taxonomic issues regarding the subspecies (Dijkstra and Jellyman 1999; Watanabe 
et al. 2006, 2008a, 2014b) and populations (Minegishi et al. 2008; Watanabe et al. 2008b).

Catadromous anguillid eels occur in freshwater habitats during their growth stages and reproduce in the ocean environment. As a result, life history data on their reproduction is completely lacking and they are often referred to as 'mysterious creatures' (Kuroki and Tsukamoto 2012). Anguillid eels have a widespread global distribution, from tropic to subarctic zones (Fig. 1), however, they do not occur along the west coasts of the North and South American continents, the west coast of Africa, and the east coast of South America, except the north coast along the Caribbean Sea.

Anguillid eels are important food and cultural resources across the world (Kuroki et al. 2014a), but their populations have drastically decreased worldwide over the past few decades. The International Union for Conservation of Nature (IUCN) evaluated 13 species of anguillid eels and categorized A. anguilla as a critically endangered species, A. japonica and A. rostrata as endangered species, A. borneensis as a vulnerable species, and the remaining species as near threatened, least concern or data deficient species in the list (IUCN 2019). After the IUCN evaluation, the endangered status of Anguilla species has become a frequently broadcasted topic by the mass media and, hence, common names have also been used frequently. In addition, the shortage of temperate eel resources induced a new exploitation of tropical eels in temperate regions. Such eel resources had previously only been consumed at the local level and far less scientific research had been conducted regarding such eels compared to temperate eels. This situation resulted in the urgent need for common names.

The common names of freshwater eels of anguillid eels are now inconsistent among mass media articles, online resources, and even scientific publications (Table 1). Some lists and books do not discriminate between subspecies (IUCN 2019) and cover only some of the species in the genus Anguilla (Wheeler et al. 1992; Nelson et al. 2013; FishBase 2019). Furthermore, some common names do not necessarily represent their geographic distribution sufficiently, which is important to recognize the biological characteristic of the species (Yamamoto et al. 2000; FishBase 2019; IUCN 2019; Wikipedia 2020).

The objective of the study was to propose standard common names for all anguillid species and subspecies under fixed rules based on the available scientific information, and that the frequent changing of names should strictly be avoided.

\section{Materials and methods}

Rules for common names.

We defined the following five rules in naming anguillid eels:

(1) Use a locality name of the geographic distribution of the species or subspecies.

(2) Distinguish two sympatric species or subspecies as longfin or shortfin.

(3) Select a name that would enable the scientific name to be easily recalled.

(4) Value longstanding former common names if they adhere to the above three rules.

(5) Use the shortest name possible.

Reasons for the rule

Anguillid eels cannot be identified only by their morphological characters because of an overlapping of traits (Ege 1939; Watanabe et al. 2004). A Danish ichthyologist, Vincent Ege, faced this problem 80 years ago, and proposed a solution by using geographic distribution information of each species. He initially divided all anguillid eels into four groups using three clearly distinguishable morphological characters, i.e., the patterns of the skin (mottled or plane), width of the maxillary band (wide or narrow), and length of the dorsal fin (long or short) (Fig. 2). Ege then identified the species in each group using differences in their geographic distributions (Fig. 1). Therefore, the locality name was thus the most important characteristic in our propose rules for the common names of anguillid eels (Rule 1).

The length of the dorsal fin (longfin or shortfin) is a relatively easy external character to observe in anguillid eels (Rule 2). When the proportion of the ano-dorsal length (distance between the verticals of the origins of the dorsal and anal fins) to the total length is greater than $6 \%$, it is classified as a longfin eel, and when the proportion is less than or equal to $6 \%$, it is classified as a shortfin eel (Fig. 2; Watanabe et al. 2004). Body color pattern, i.e., mottled or plane, is also a distinguishable character at the immature yellow eel 
Fig. 1 Ege's four groups of morphologically divided anguillid eels and the geographic distribution of each species in each group (Ege 1939), including the geographic distribution of the newly discovered Anguilla luzonensis (Watanabe et al. 2009a)
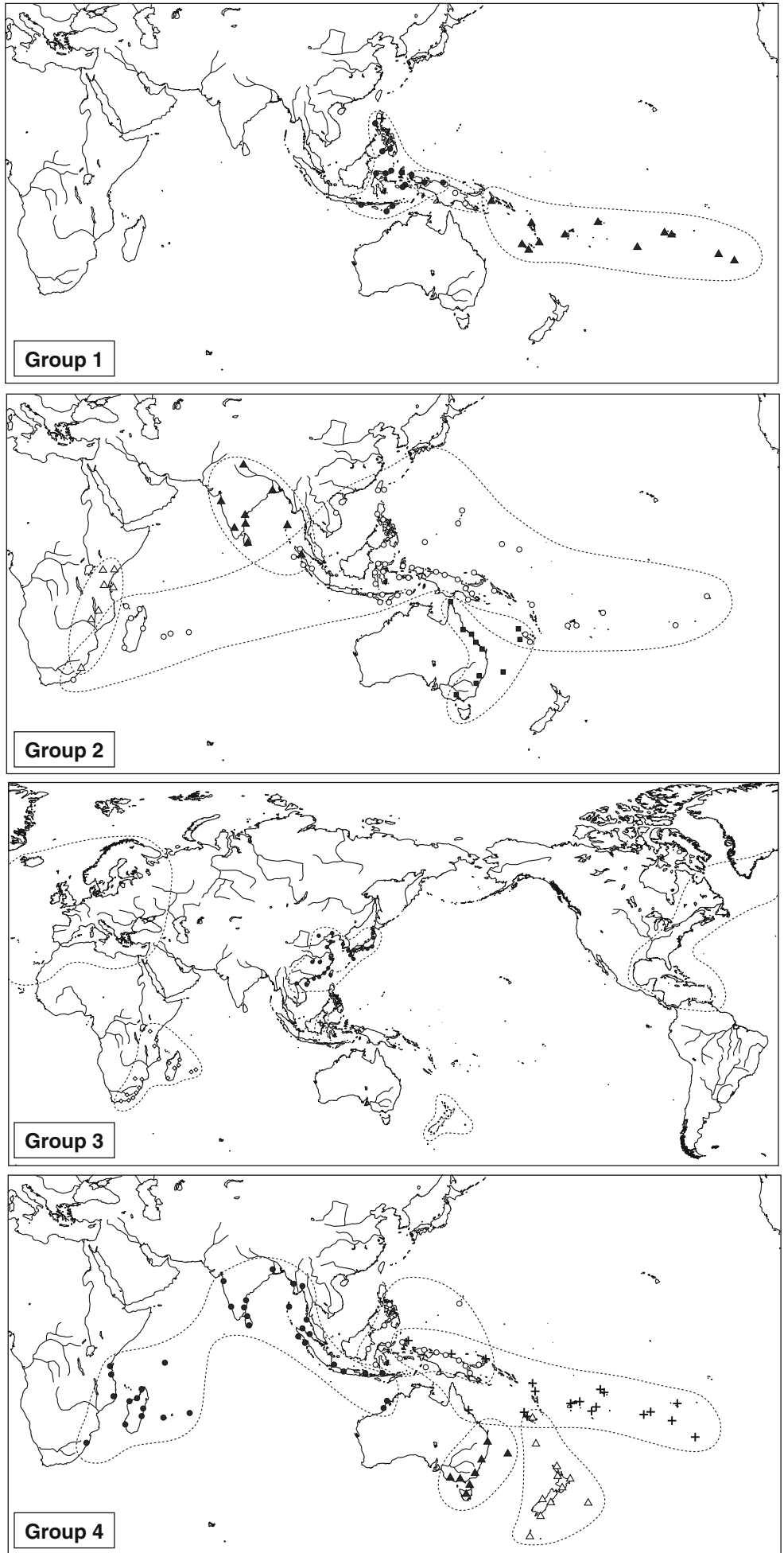

stage, but cannot be used at the juvenile as glass eel stage, is unclear at the pigmented elver stage, and is even more difficult to distinguish in matured silver eels wherein patterns become vague and appear to be 'plane' 
Fig. 2 Morphological characteristics of Ege's four groups of anguillid eels. (modified from Watanabe 2003)

\section{a Group 1}

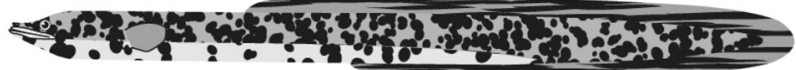

b Group 2

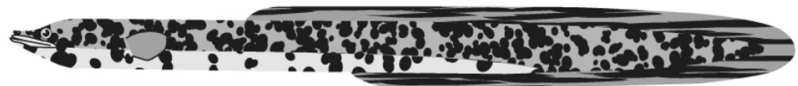

C Group 3

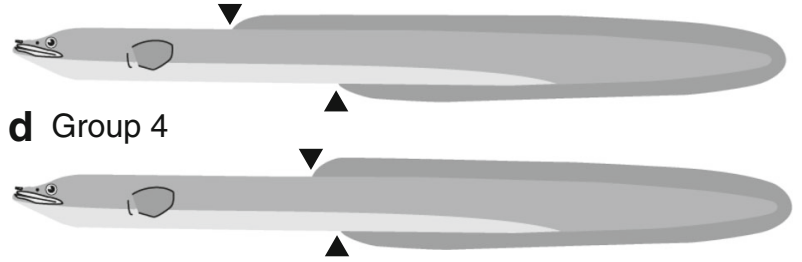

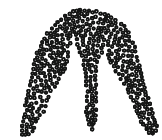

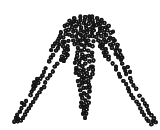

even in species with mottled skin. Therefore, this character, which can vary among developmental stages, was not used as a rule for common names in the present study. The width of the maxillary band is also difficult to observe because of its position inside the mouth and is thus inconvenient for market use.

If the scientific name can be easily recalled from the common name, the similarity would increase simplicity and avoid confusion because scientific names are strictly defined and relatively more stable than common names (Rule 3). We considered that longstanding and widely used common names should also be valued (Rule 4). Moreover, shorter names are easier to remember (Rule 5). We applied these rules to the currently known 19 anguillid eel species and subspecies to define their common names.

\section{Results and discussion}

Based on the application of the five rules, we proposed 22 common names for the 19 species and subspecies of anguillid eels (Table 1). These names can be used to distinguish all anguillid species in the world, including 16 species and six subspecies. Specifically, 21 species and subspecies were named based on Rule (1) (locality name), 6 by Rule (2) (longfin or shortfin), 13 by Rule (3) (scientific name), and 3 by Rule (4) (longstanding common name).

We proposed 22 different common names for all 19 taxonomically classified species and subspecies of anguillid eels, including the three species that each have two subspecies (A. bengalensis, A. bicolor, A. australis). It is important to simultaneously give common names to all species and subspecies, because they are all presently taxonomically authorized and thus both require common names. It is also important to use fixed rules when allocating common names to species, to give users a systematic understanding and ensure that they are easy to remember.

The geographic distribution of species was important in Ege's taxonomic classification of anguillid eels. All proposed common names, except one (Bicolor eel) have locality information in their names. This information reminds users of the geographic distribution of the species and subspecies and thus makes the common names easier to remember. However, the geographic distributions of A. interioris and A. luzonensis are not yet fully defined. Especially, A. luzonensis is a newly discovered cryptic species (Watanabe et al. 2009a) and its distribution is reported only in the Philippines and Taiwan (Teng et al. 2009; Watanabe et al. 2009a; Kuroki et al. 2012; Aoyama et al. 2015; Shinoda et al. 2015; Shirotori et al. 2016). Further investigations are needed to define the exact geographic distribution limits of these species.

Taxonomic confusion of scientific names (Watanabe et al. 2014a) may cause issues regarding the common names of anguillid species. Three species in the genus Anguilla (A. bengalensis, A. bicolor, and A. australis) each have two subspecies, which has caused taxonomic discussion (Dijkstra and Jellyman 1999; Watanabe et al. 2005, 2006, 2008a, 2014b; Minegishi et al. 2012). Issues regarding subspecies can be resolved in the future by avoiding classification into subspecies or by elevating the rank of subspecies to species. For future taxonomic reorganization, and to reduce confusion from taxonomic changes, we allocated these three 


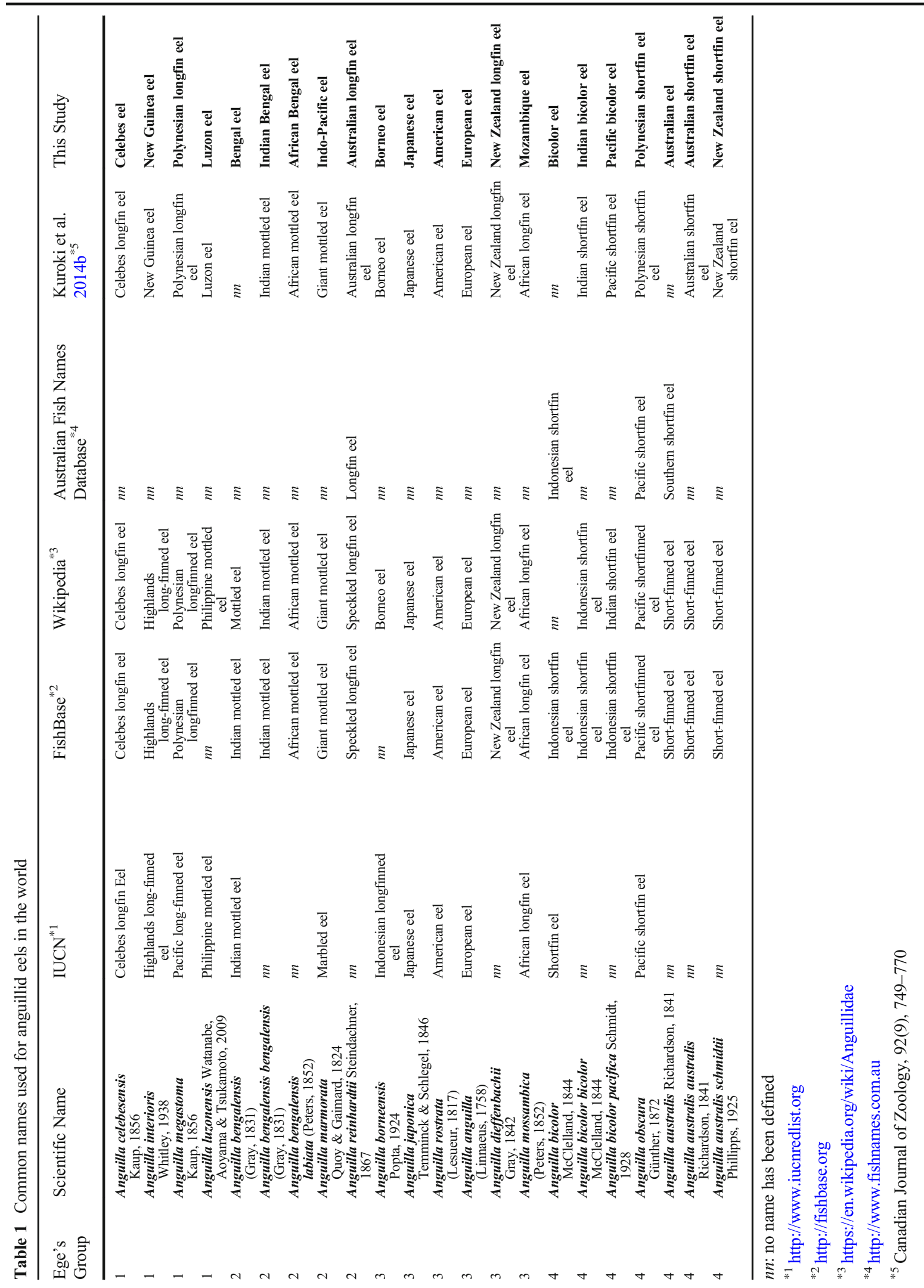


species, as well as their six subspecies, common names.

There are problems when allocating common names to species, e.g., regarding the populations and geographic distributions of the species. For example, we name A. marmorata as the "Indo-Pacific eel" considering their wide geographic distribution from the western Indian Ocean to the eastern Pacific. This species has the widest geographic distribution of all anguillid species in the world, with at least four populations (Ishikawa et al. 2004; Minegishi et al. 2008; Watanabe et al. 2008b, 2009b; Gagnaire et al. 2011), i.e., in the North Pacific, South Pacific, in the waters surrounding Guam, and in the Indian Ocean. If these populations are recognized as separate species, additional common names will be needed to distinguish them. In addition, the possibility of segregating other species, such as A. celebesensis, A. bengalensis, and even the well-studied A. anguilla and A. japonica, into different populations have been discussed. The progression of science and advancement of classification techniques can change the taxonomic status of a species and thus the common names will also need alteration.

Hybridization may pose another problem in naming. The occurrence of eel hybrids was first reported in the Atlantic eels, A. anguilla and A. rostrata in Iceland (Avise et al. 1990; Avise 2003; Albert et al. 2006). Recently, the existence of hybrids has been discussed in tropical eels (Schabetsberger et al. 2015; Barth et al. 2020). The reproductive isolation mechanism that closely relates to the occurrence of natural hybrids is not well understood in anguillid eels because their spawning areas are located far offshore and thus are not easy to investigate. The spawning areas of the two Atlantic eel species are considered to overlap in the Sargasso Sea (McCleave et al. 1987), and A. marmorata and A. japonica also breed sympatrically in areas west of the Mariana Islands (Chow et al. 2009; Kuroki et al. 2009). These cases could lead to hybridization and raise other taxonomic problems.

The location of the spawning area in the ocean is important to consider with regards to the geographic distribution of catadromous anguillid eels. Ocean current systems connect the offshore breeding locations and the continental growth habitats, and as a result, the geographic distribution of species can be passively determined. Future investigations regarding the locations of the spawning areas of each anguillid species may promote a better understanding of the geographic distributions of species, and such information may be useful for the allocation of common names.

Acknowledgements This study was partially supported by JSPS KAKENHI Grant Number 6252030, 17 K19300 to K.T., $25450270,17 \mathrm{H} 03859$ to K.M., and 26450268 , $17 \mathrm{~K} 07921$ to S.W., and a Grant for Scientific Research from the Faculty of Agriculture, Kindai University to S.W.

Open Access This article is licensed under a Creative Commons Attribution 4.0 International License, which permits use, sharing, adaptation, distribution and reproduction in any medium or format, as long as you give appropriate credit to the original author(s) and the source, provide a link to the Creative Commons licence, and indicate if changes were made. The images or other third party material in this article are included in the article's Creative Commons licence, unless indicated otherwise in a credit line to the material. If material is not included in the article's Creative Commons licence and your intended use is not permitted by statutory regulation or exceeds the permitted use, you will need to obtain permission directly from the copyright holder. To view a copy of this licence, visit http://creativecommons.org/licenses/by/4.0/.

\section{References}

Albert V, Jónsson B, Bernatchez L (2006) Natural hybrids in Atlantic eels (Anguilla anguilla, A. rostrata): evidence for successful reproduction and fluctuating abundance in space and time. Mol Ecol 15:1903-1916

Aoyama J, Yoshinaga T, Shinoda A, Shirotori F, Yambot AV, Han Y-S (2015) Seasonal changes in species composition of glass eels of the genus Anguilla (Teleostei: Anguillidae) recruiting to the Cagayan River, Luzon Island, the Philippines. Pac Sci 69:261-268

Avise JC (2003) Catadromous eels of the North Atlantic: a review of molecular genetic findings relevant to natural history, population structure, speciation, and phylogeny. In: Aida K, Tsukamoto K, Yamauchi K (eds) Eel Biology. SpringerVerlag, Tokyo, pp 31-48

Avise JC, Nelson WS, Arnold J, Koehn RK (1990) The evolutionary genetic status of Icelandic eels. Evolution 44:1254 1262

Barth JMI, Gubili C, Matschiner M, Tørresen OK, Watanabe S, Egger B, Han Y-S, Feunteun E, Sommaruga R, Jehle R, Schabetsberger R (2020) Stable species boundaries despite ten million years of hybridization in tropical eels. Nat Commun 11:1433

Castle PHJ, Williamson GR (1974) On the validity of the freshwater eel species Anguilla ancestralis Ege from Celebes. Copeia 1974:569-570

Chow S, Kurogi H, Mochioka N, Kaji S, Okazaki M, Tsukamoto K (2009) Discovery of mature freshwater eels in the open ocean. Fish Sci 75:257-259

Dijkstra LH, Jellyman DJ (1999) Is the subspecies classification of the freshwater eels Anguilla australis australis Richardson 
and A. a. schmidtii Phillipps still valid? Mar Freshwater Res 50:261-263

Ege V (1939) A revision of the genus Anguilla Shaw, a systematic, phylogenetic and geographical study. Dana Rep 16:1-256

FishBase (2019) Froese, R. and D. Pauly (Eds.). Worldwide web electronic publication. Version 12/2019. https://www. fishbase.org. Accessed 03 Mar 2020

Gagnaire PA, Minegishi Y, Zenboudgi S, Valade P, Aoyama J, Berrebi P (2011) Within-population structure highlighted by differential introgression across semipermeable barriers to gene flow in Anguilla marmorata. Evolution 65:3413-3427

International Commission on Zoological Nomenclature (2020) https://www.iczn.org. Accessed 03 Mar 2020

Ishikawa S, Tsukamoto K, Nishida M (2004) Genetic evidence for multiple geographic populations of the giant mottled eel Anguilla marmorata in the Pacific and Indian oceans. Icthyol Res 51:343-353

IUCN (International Union for Conservation of Nature) (2019) The IUCN Red List of Threatened Species. Version 2019-3. https://www.iucnredlist.org. Accessed 03 Mar 2020

Kuroki M, Aoyama J, Miller MJ, Yoshinaga T, Shinoda A, Hagihara S, Tsukamoto K (2009) Sympatric spawning of Anguilla marmorata and Anguilla japonica in the western North Pacific Ocean. J Fish Biol 74:1853-1865

Kuroki M, Tsukamoto K (2012) Eels on the move -Mysterious creatures over millions of years. Tokai University Press, Tokyo

Kuroki M, Miller MJ, Aoyama J, Watanabe S, Yoshinaga T, Tsukamoto K (2012) Evidence of offshore spawning for the newly discovered anguillid species Anguilla luzonensis (Teleostei: Anguillidae) in the western North Pacific. Pac Sci 66:497-508

Kuroki M, Righton D, Walker AM (2014a) The importance of Anguillids: a cultural and historical perspective introducing papers from the World Fisheries Congress. Ecol Freshw Fish 23:2-6

Kuroki M, Miller MJ, Tsukamoto K (2014b) Diversity of early life-history traits in freshwater eels and the evolution of their oceanic migrations. Can J Zool 92:749-770

McCleave JD, Kleckner RC, Castonguay M (1987) Reproductive sympatry of American and European eels and implications for migration and taxonomy. Am Fish Soc Symp 1:286-297

Minegishi Y, Aoyama J, Tsukamoto K (2008) Multiple population structure of the giant mottled eel Anguilla marmorata. Mol Ecol 17:3109-3122

Minegishi Y, Gagnaire P-A, Aoyama J, Bosc P, Feunteun E, Tsukamoto K, Berrebi P (2012) Present and past genetic connectivity of the Indo-Pacific tropical eel Anguilla bicolor. J Biogeogr 39:408-420

Nelson JS, Crossman EJ, Espinosa-Perez H, Findley LT, Gilbert CR, Lea RN, Williams JD (2013) Common and scientific names of fishes from the United States, Canada, and Mexico, 7th edition. Special Publication 34. Am Fish Soc, Bethesda, MD

Schabetsberger R, Økland F, Kalfatak D, Sichrowsky U, Tambets M, Aarestrup K, Gubili C, Sarginson J, Boufana B, Jehle R, Dall'Olmo G, Miller MJ, Scheck A, Kaiser R, Quartly G (2015) Genetic and migratory evidence for sympatric spawning of tropical Pacific eels from Vanuatu. Mar Ecol Prog Ser 521:171-187
Shinoda A, Yoshinaga T, Aoyama J, Tsuchida G, Nakazato S, Ishikawa M, Matsugamoto Y, Watanabe S, Azanza RV, Tsukamoto K (2015) Early life history of the Luzon mottled eel Anguilla luzonensis recruited to the Cagayan River, Luzon Island, the Philippines. Coast Mar Sci 38:21-26

Shirotori F, Ishikawa T, Tanaka C, Aoyama J, Shinoda A, Yambot AV, Yoshinaga T (2016) Species composition of anguillid glass eels recruited at southern Mindanao Island, the Philippines. Fish Sci 82:915-922

Teng HY, Lin Y-S, Tzeng C-S (2009) A new Anguilla species and reanalysis of the phylogeny of freshwater eels. Zool Stud 48 : 808-822

Watanabe S (2003) Taxonomy of the freshwater eels, genus Anguilla Schrank, 1798. In: Aida K, Tsukamoto K, Yamauchi K (eds) Eel Biology. Springer-Verlag, Tokyo, pp 3-18

Watanabe S, Aoyama J, Tsukamoto K (2004) Reexamination of Ege's (1939) use of taxonomic characters of the genus Anguilla. B Mar Sci 74:337-351

Watanabe S, Aoyama J, Nishida M, Tsukamoto K (2005) A molecular genetic evaluation of the taxonomy of eels of the genus Anguilla (Pisces: Anguilliformes). Bull Mar Sci 76: 675-690

Watanabe S, Aoyama J, Tsukamoto K (2006) Reconfirmation of morphological differences between A. australis australis Richardson and A. australis schmidtii Phillipps. New Zeal J Mar Fresh 40:325-331

Watanabe S, Aoyama J, Tsukamoto K (2008a) The use of morphological and molecular genetic variations to evaluate subspecies issues in the genus Anguilla. Coast Mar Sci 32:19-29

Watanabe S, Aoyama J, Miller MJ, Ishikawa S, Feunteun E, Tsukamoto K (2008b) Evidence of population structure in the giant mottled eel, Anguilla marmorata, using total number of vertebrae. Copeia 2008:680-688

Watanabe S, Aoyama J, Tsukamoto K (2009a) A new species of freshwater eel, Anguilla luzonensis (Teleostei: Anguillidae) from Luzon Island of the Philippines. Fish Sci 75:387-392

Watanabe S, Miller MJ, Aoyama J, Tsukamoto K (2009b) Morphological and meristic evaluation of the population structure of Anguilla marmorata across its range. J Fish Biol 74:2069-2093

Watanabe S, Aoyama J, Tsukamoto K (2014a) On the Identities of Anguilla borneensis, A. malgumora, and Muraena malgumora. Copeia 2014:568-576

Watanabe S, Miller MJ, Aoyama J, Tsukamoto K (2014b) Evaluation of the population structure of Anguilla bicolor and $A$. bengalensis using total number of vertebrae and consideration of the subspecies concept for the genus Anguilla. Ecol Freshw Fish 23:77-85

Wheeler A (1992) A list of the common and scientific names of fishes of the British Isles. J Fish Biol 41:17-26

Wikipedia (2020) https://en.wikipedia.org/wiki/Anguillidae. Accessed 03 Mar 2020

Yamamoto T, Mochioka N, Nakazono A (2000) Occurrence of the third Anguilla species, Anguilla bicolor pacifica glass-eels, from Japan. Aquac Sci 48:579-580

Publisher's note Springer Nature remains neutral with regard to jurisdictional claims in published maps and institutional affiliations. 